\title{
Evaluation of Potential Geographic Distribution for Large-Scale Photovoltaic System in Suburbs of China
}

\author{
Masashi Kawase, Keiichi Okajima, and Yohji Uchiyama \\ Department of Risk Engineering, University of Tsukuba, Tsukuba 3058573, Japan \\ Correspondence should be addressed to Masashi Kawase; s1220592@u.tsukuba.ac.jp
}

Received 19 February 2013; Accepted 24 June 2013

Academic Editor: Zuhal Oktay

Copyright ( 2013 Masashi Kawase et al. This is an open access article distributed under the Creative Commons Attribution License, which permits unrestricted use, distribution, and reproduction in any medium, provided the original work is properly cited.

\begin{abstract}
Since China is the largest $\mathrm{CO}_{2}$ emitting country in the world, photovoltaic (PV) systems are expected to be widely installed to reduce $\mathrm{CO}_{2}$ emission. In general, available area for PV installation depends on urban area due to differences in land use and slope. Amount of electricity generated by a PV system also depends on urban area because of differences in solar irradiation and ambient temperature. The aim of this study is to evaluate the installation of large-scale PV systems in suburbs of China, taking these differences into consideration. We have used a geographic information system (GIS) to evaluate amounts of installation capacity of large-scale PV systems, electricity generated, and $\mathrm{CO}_{2}$ emission reduction by the installation capacity of large-scale PV systems in suburbs of Liaoning, Shanghai, Anhui, and Guangdong. In Liaoning, the amount of $\mathrm{CO}_{2}$ emission reduction by the installation capacity of large-scale PV systems was estimated to be the largest, $3,058 \mathrm{kt}-\mathrm{CO}_{2} / \mathrm{yr}$, due to its larger amount of the installation capacity, 2439.4 MW, than the amount of the installation capacity in other regions.
\end{abstract}

\section{Introduction}

According to the World Energy Outlook of IEA, the demand of annual primary energy in China is expected to be 3,737 Mtoe by 2035, about 1.8 times the energy consumption of China in 2008 [1]. In addition, China exhausts the most amount of $\mathrm{CO}_{2}$ and has emitted $6877.2 \mathrm{Mt}-\mathrm{CO}_{2}$ in 2009 [2]. Therefore, China has a large potential to reduce $\mathrm{CO}_{2}$ emission in the Asian region, and the $\mathrm{CO}_{2}$ emission reduction in China has an impact on the global warming.

The Chinese government currently focuses on renewable energy to reduce $\mathrm{CO}_{2}$ emission. In the 12th Five Year Plan for Renewable Energy Development (2011-2015), the share of renewable forms of energy such as hydropower, wind, solar, and biomass is to be increased. Although the installed photovoltaic (PV) capacity was around $700 \mathrm{MW}$ at the yearend 2010, and the State Council, China's national cabinet, has now raised the target for solar energy to an unprecedented level of $9 \mathrm{GW}$ of PV installations by 2015 [3]. Thus, it is expected that large-scale PV systems will be widely installed in order to achieve this target.

There are few studies regarding installation of PV systems in China. Zhang et al. estimated cumulative installation of
PV cells for large-scale PV power in China considering subsidy on PV installation and the electricity supply mix [4]. Ito et al. designed a very large-scale PV of $100 \mathrm{MW}$ system in Gobi desert [5]. Byrne et al. assessed the economics and livelihoods impacts of stand-alone, small-scale PV system installation [6]. However, those studies give no explanation about potential of large-scale PV system based on the geographic feasibility analysis. In general, available area for a large-scale PV system depends on the specific urban area because of regional differences in land use, land slope, and the distance to the power-consuming area. The amount of electricity generated by a PV system also depends on the regional differences in solar irradiation and ambient temperature. Thus, the installation of large-scale PV systems should be evaluated for a specific region to account for these regional differences.

This study aims to estimate the geographical distribution of the available area for large-scale PV systems in China using the geographic information system (GIS). The GIS is an effective tool for the regional evaluation of the feasibility of the installation of large-scale PV systems and takes the regional differences into consideration. In this study, the available area for large-scale PV systems has been estimated. 


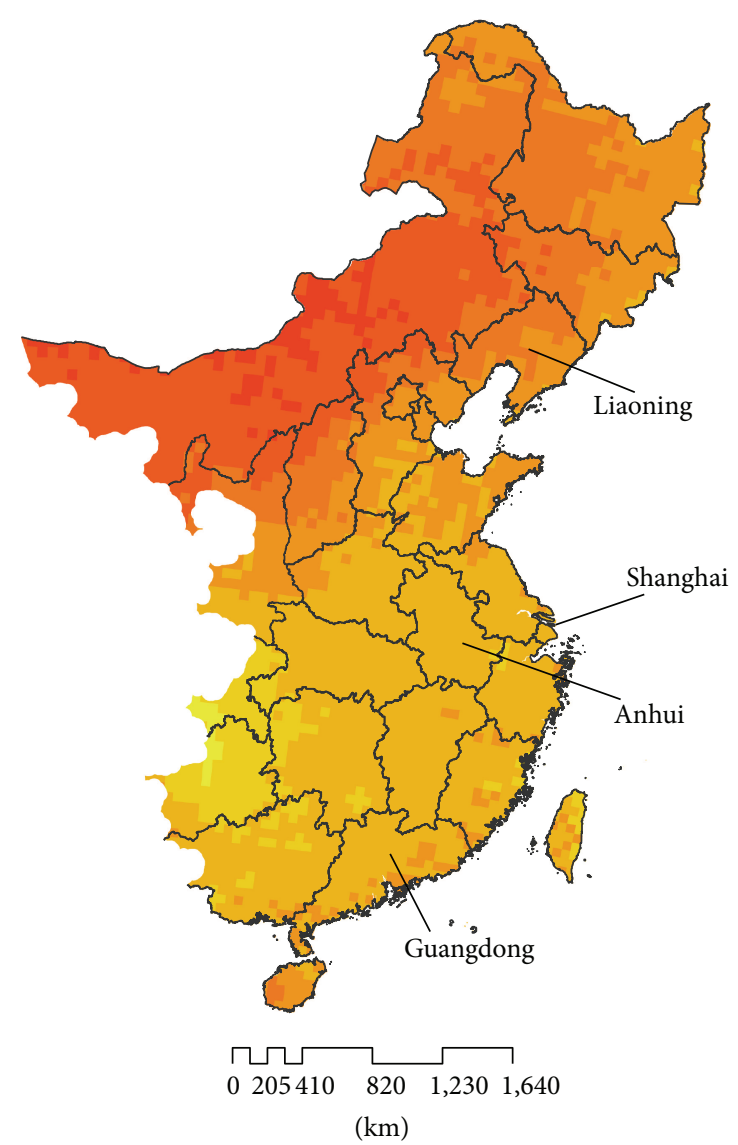

Annual average latitude

tilt solar irradiation $\left(\mathrm{kWh} /\left(\mathrm{m}^{2} \cdot\right.\right.$ day $\left.)\right)$
$3.13-3.50$
$3.51-4.00$
$4.51-5.00$
$5.01-5.50$
$5.51-6.00$
$6.01-6.50$
$6.51-7.00$
$7.01-7.50$

FIGURE 1: Distribution of tilt solar irradiation.

Thereafter, the installation capacity of the large-scale PV system, the electricity generated, and the $\mathrm{CO}_{2}$ emission reduction is also evaluated. Finally, we have analyzed keyfactors of the regional differences in $\mathrm{CO}_{2}$ emission reduction.

\section{Study Areas}

First of all, distribution of tilt solar irradiation in China was clarified by using GIS data of Solar and Wind Energy Resource Assessment (SWERA) [7]. Figure 1 shows that the solar irradiation of coastal area in northeastern China is larger than that in southern or southeastern China. Four regions, Liaoning, Shanghai, Anhui, and Guangdong are considered as a subject area for study, because these regions are located on coastal area which is assumed to have a large number of urban area with strong demand for electrical power.

\section{Methods}

3.1. Estimation of Available Area for a Large-Scale PV System. For the installation of a large-scale PV system, an important

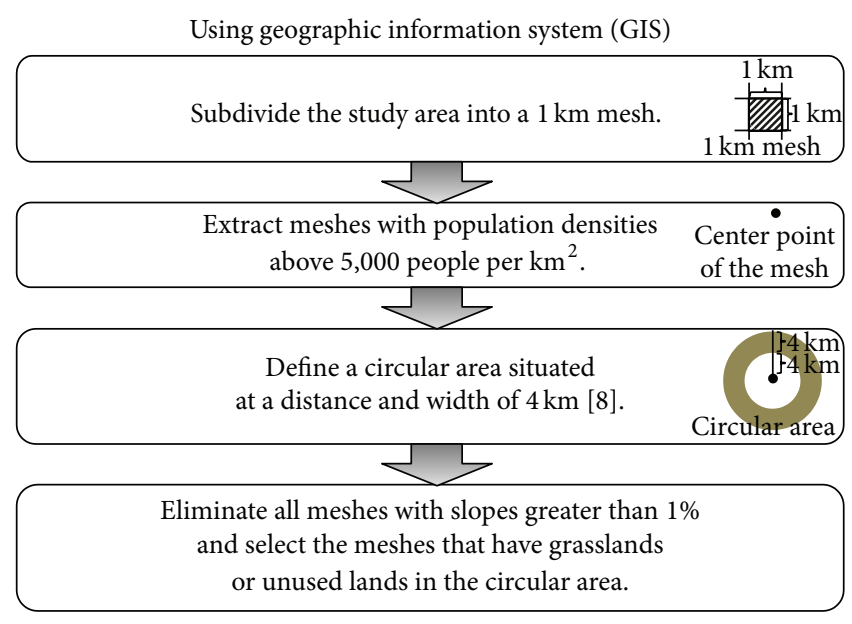

FIGURE 2: Steps of estimation of available area.

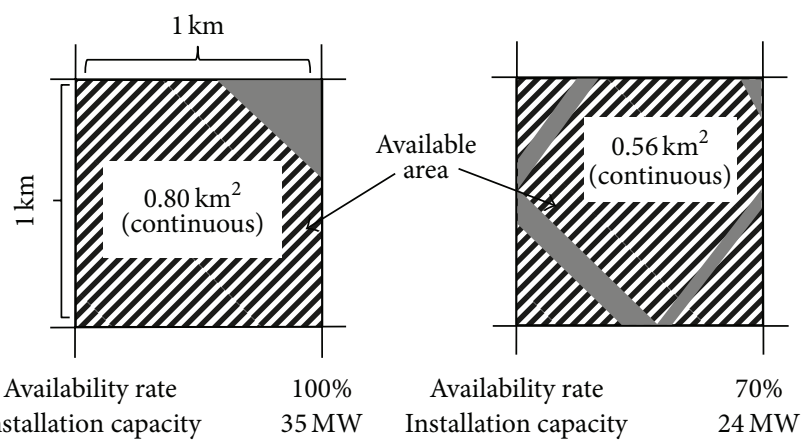

FIGURE 3: Samples of available area at availability rate (100\%, 70\%).

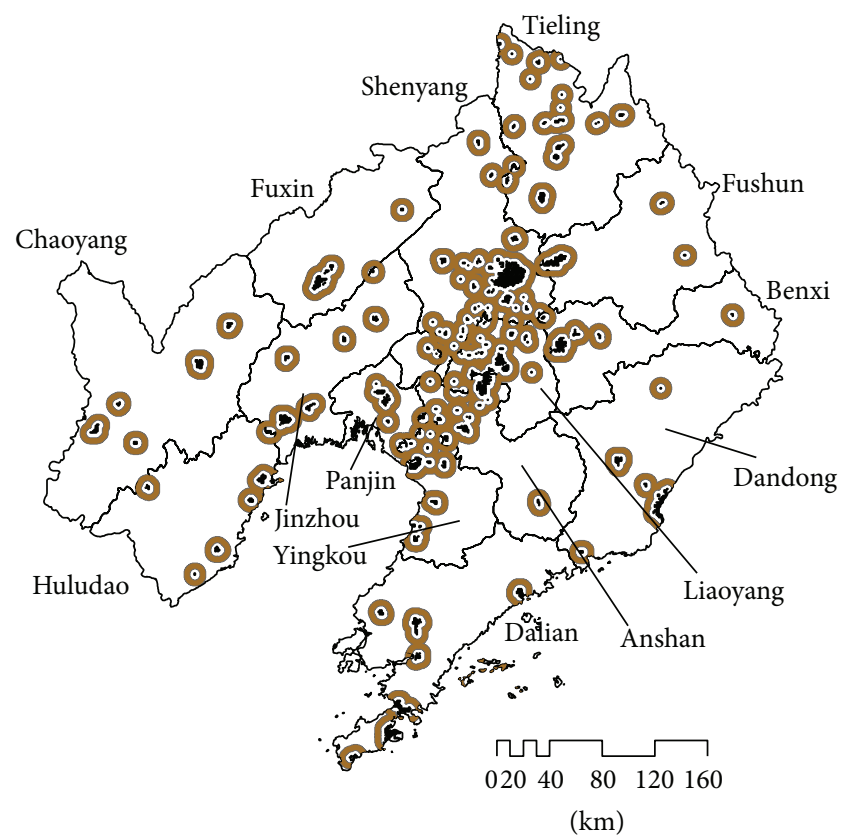

- Area with population densities above 5,000 people per $\mathrm{km}^{2}$
- Circular area
$\square$ City boundary

FIGURE 4: Distribution of the circular area in Liaoning. 


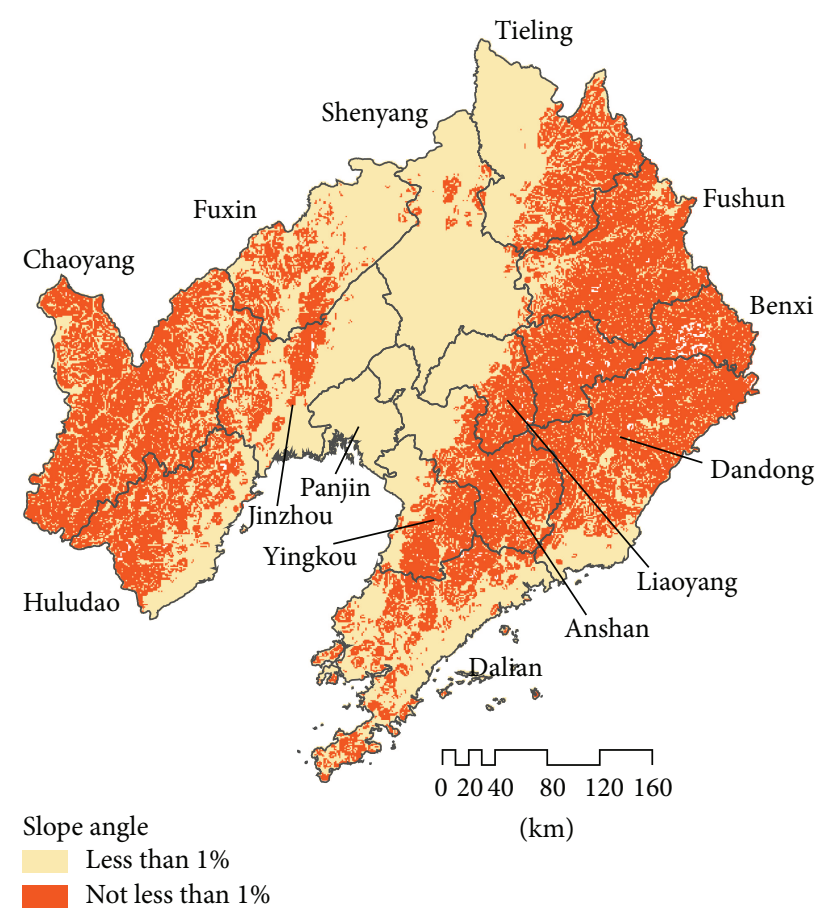

FIgURE 5: Distribution of slope angle in Liaoning.

factor is the proximity to the power-consuming area. Land slope is also an important factor because it may drive up the construction costs of a large-scale PV system. Land use is a fundamentally important factor. Therefore, we defined the available area for a large-scale PV system as area that meets the following three requirements.

(1) A circular area situated at a distance and width of $4 \mathrm{~km}$ from the outer limits of area with population densities greater than 5,000 people per $\mathrm{km}^{2}$ to the circumference of the circle (circular area) [8].

(2) Land sites with slopes less than $1 \%$.

(3) Grassland and unused land.

Figure 2 shows steps of estimation of available area for a large-scale PV system. Using GIS, we first subdivided the study area into a $1 \mathrm{~km}$ mesh. Second, we extracted meshes with population densities above 5,000 people per $\mathrm{km}^{2}$. Thereafter, we defined a circular area situated at a distance and width of $4 \mathrm{~km}$ from the outer limits of area with population densities greater than 5,000 people per $\mathrm{km}^{2}$ to the circumference of the circle. We eliminated all meshes with slopes greater than $1 \%$. Finally, we selected the meshes that have grassland or unused land. The population data for the meshes were obtained from population statistics data (2003) [9]. Land slope was obtained by analyzing a digital elevation model (DEM) data [10], using the GIS. The area of the grassland and unused land was obtained from the land use statistics data (2003) [9].

3.2. Estimation of Installation Capacity. Capacity larger than $20 \mathrm{MW}$ PV systems is the subject of this study. Installation

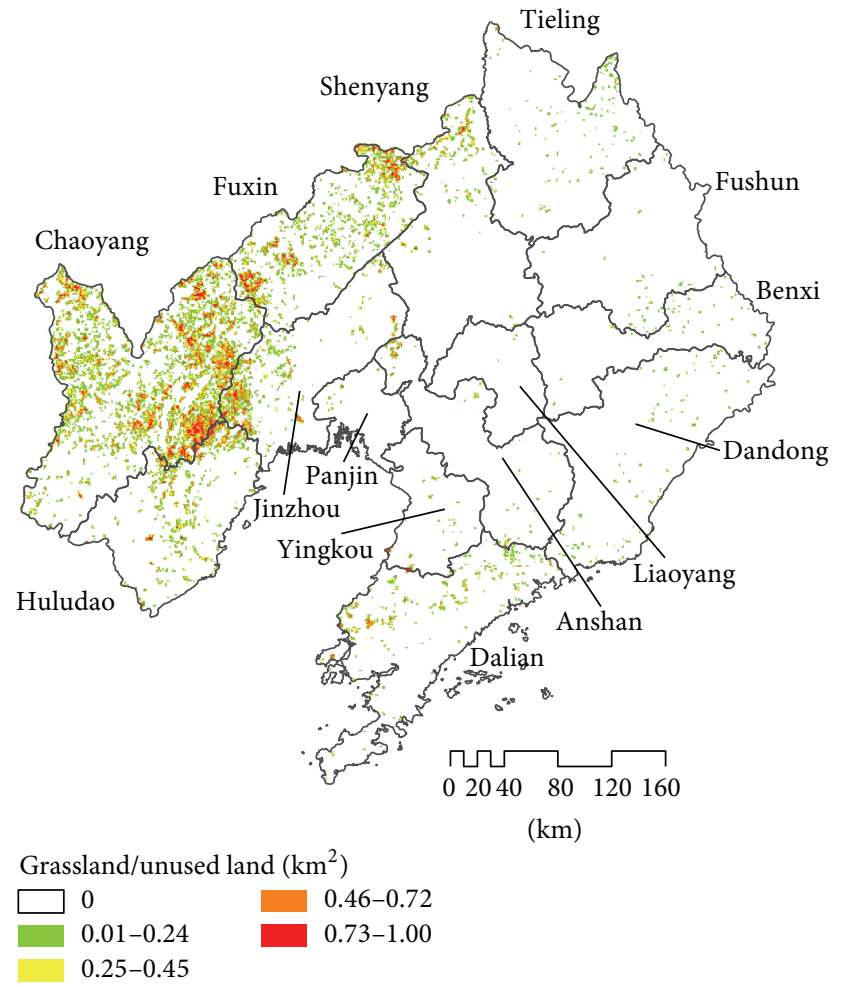

FIGURE 6: Distribution of grassland or unused land in Liaoning.

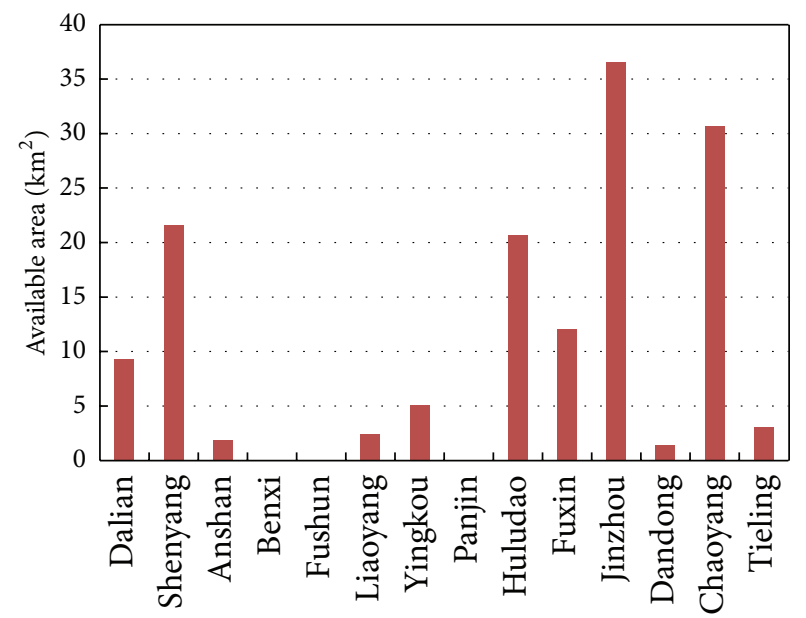

FIgURE 7: Available area for large-scale PV systems.

capacity for each region is estimated for each $1 \mathrm{~km}$ mesh. To estimate the installation capacity, we defined a PV capacity density of $44 \mathrm{MW} / \mathrm{km}^{2}$ [11]. Multiplying this density by the available area on each $1 \mathrm{~km}$ mesh yields the installation capacity. Additionally, we defined availability rates from $10 \%$ to $100 \%$ for the available area, and we assumed that available area at each availability rate is continuous area that a largescale PV system needs. We also estimated the installation capacity for each availability rate. Figure 3 shows samples of available area $\left(0.80 \mathrm{~km}^{2}\right)$ at availability rate $100 \%$ and $70 \%$. A shaded area on the left in Figure 3 shows an example of the available area at availability rate $100 \%$, and the installation 


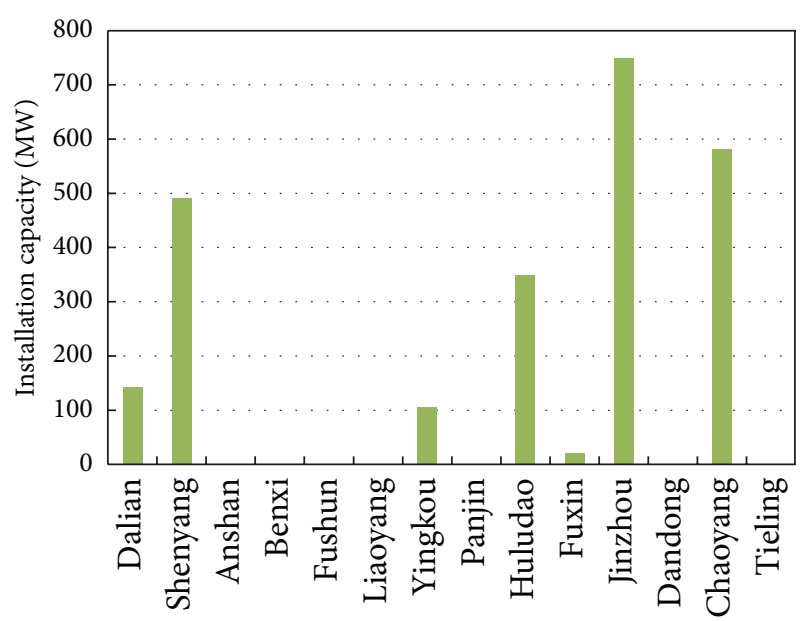

FIGURE 8: Installation capacity at availability rate $100 \%$ in each district in Liaoning.

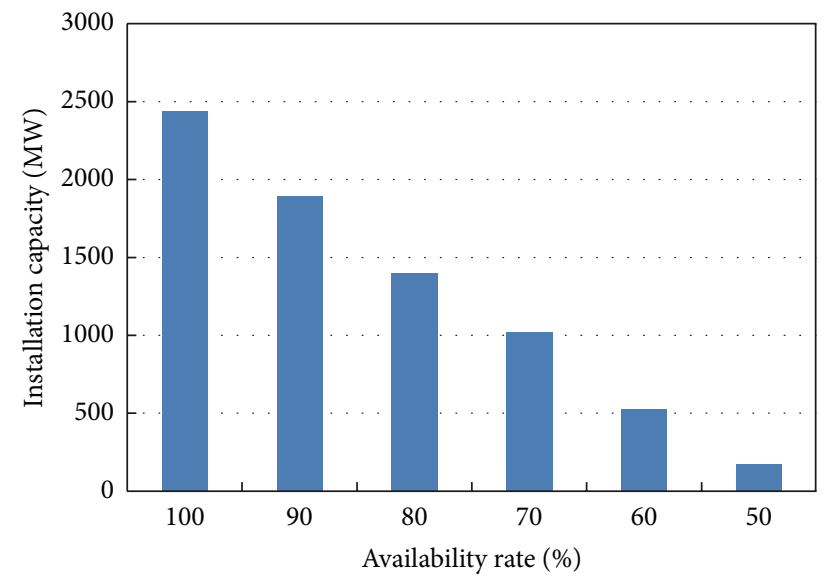

FIGURE 9: Installation capacity at each availability rate in Liaoning.

capacity in the mesh is estimated to be $35 \mathrm{MW}$ because $100 \%$ of the available area $\left(0.80 \mathrm{~km}^{2}\right)$ is assumed to be all continuous area. While a shaded area on the right in Figure 3 has also available area $\left(0.80 \mathrm{~km}^{2}\right)$ in total, the installation capacity in the mesh is estimated to be 24 MW because $70 \%$ of the available area is assumed to be continuous area $\left(0.56 \mathrm{~km}^{2}\right)$ at availability rate $70 \%$.

3.3. Calculation of Electricity Generated by the PV System. The electricity generated annually by a PV system, $E_{\mathrm{Py}}(\mathrm{kWh})$, for each $1 \mathrm{~km}$ mesh is estimated from (1) [12] as

$$
E_{\mathrm{Py}}=\sum E_{\mathrm{Pm}},
$$

where $E_{\mathrm{Pm}}[\mathrm{kWh}]$ is the monthly energy generation for each $1 \mathrm{~km}$ mesh and is estimated from (2) [13] as

$$
E_{\mathrm{Pm}}=K \times P_{\mathrm{AS}} \times \frac{H_{\mathrm{Am}}}{G_{\mathrm{S}}},
$$

where $K$ is the performance ratio of the PV system, which is obtained from (3) [13]; $P_{\mathrm{AS}}(\mathrm{kW})$ is the nominal power of

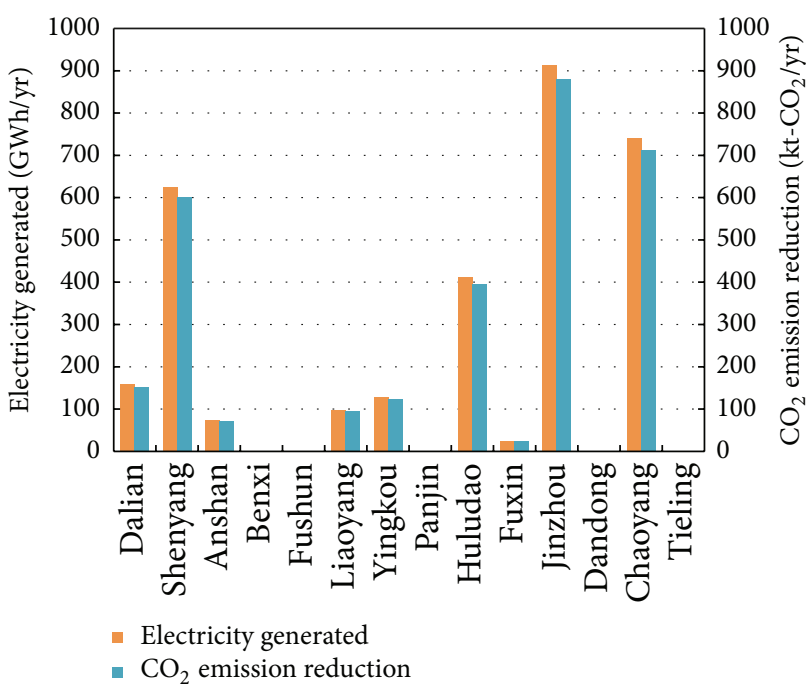

FIGURE 10: Total amounts of electricity generated and $\mathrm{CO}_{2}$ emission reduction in each district of Liaoning.

the PV array under standard test conditions; $H_{\mathrm{Am}}\left(\mathrm{kWh} / \mathrm{m}^{2}\right.$. month) is the monthly total solar irradiation tilted at latitude on each $1 \mathrm{~km}$ mesh; $G_{S}$ is the total irradiance under standard test conditions, which is $1.0 \mathrm{~kW} / \mathrm{m}^{2}$ [12]. $H_{\mathrm{Am}}$ is obtained from the GIS data on Solar and Wind Energy Resource Assessment (SWERA) [7] as

$$
K=K_{\mathrm{HD}} \times K_{\mathrm{PD}} \times K_{\mathrm{PM}} \times K_{\mathrm{PA}} \times K_{\mathrm{PT}} \times \eta_{\mathrm{INO}},
$$

where $K_{\mathrm{HD}}$ is the parameter for losses on the PV array surface; $K_{\mathrm{PD}}$ for time-dependent losses by the module function; $K_{\mathrm{PM}}$ for losses by the array load; $K_{\mathrm{PA}}$ for losses by the array circuit. $K_{\mathrm{PT}}$ is the module temperature coefficient, which is obtained from (4). $\eta_{\mathrm{INO}}$ is the effective energy efficiency of the inverter. We use the JIS recommended values of 0.97 for $K_{\mathrm{HD}}, 0.95$ for $K_{\mathrm{PD}}, 0.94$ for $K_{\mathrm{PM}}, 0.97$ for $K_{\mathrm{PA}}, 0.90$ and for $\eta_{\text {INO }}[13]$ as

$$
K_{\mathrm{PT}}=1+\alpha_{\mathrm{P} \max } \times \frac{\left(T_{\mathrm{CR}}-25\right)}{100},
$$

where $\alpha_{\mathrm{Pmax}}$ is the maximum power temperature coefficient, which is $-0.41^{\circ} \mathrm{C}^{-1}$ for c-Si PV modules; $T_{\mathrm{CR}}\left({ }^{\circ} \mathrm{C}\right)$ is the temperature of the PV module, which is obtained from (5) [13] as

$$
T_{\mathrm{CR}}=T_{\mathrm{AV}}+\Delta T,
$$

where $T_{\mathrm{AV}}\left({ }^{\circ} \mathrm{C}\right)$ is the daily ambient temperature profile averaged over month; $\Delta T\left({ }^{\circ} \mathrm{C}\right)$ is the weighted average of the annual increase of module temperature. We obtained $T_{\mathrm{AV}}$ for that region from the World Surface Data (2009) [14]. We used a value of $18.4^{\circ} \mathrm{C}$ for $\Delta T$ for PV systems mounted on racks [13].

3.4. Calculation of $\mathrm{CO}_{2}$ Emission Reduction. Annual $\mathrm{CO}_{2}$ emission reduction, $\mathrm{ER}_{\mathrm{CO}_{2}}\left[\mathrm{t}-\mathrm{CO}_{2} / \mathrm{yr}\right]$, by the $\mathrm{PV}$ system is obtained from following equation:

$$
\mathrm{ER}_{\mathrm{CO}_{2}}=\mathrm{RF}_{\mathrm{CO}_{2}} \times \mathrm{EG},
$$




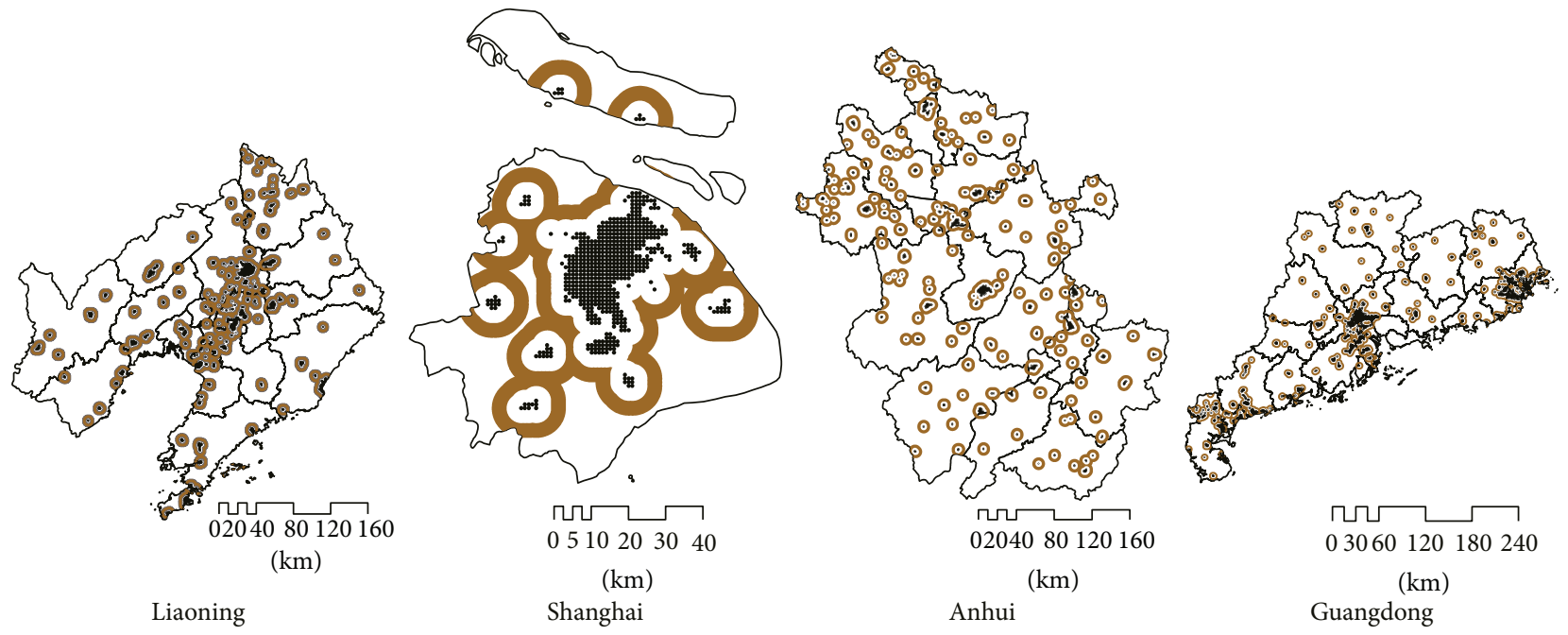

- Area with population densities above 5,000 people per $\mathrm{km}^{2}$

- Circular area

$\square$ City boundary

FIgURE 11: Distribution of the circular area in each region.

TABLE 1: Value of $\mathrm{RF}_{\mathrm{CO}_{2}}$ for each region.

\begin{tabular}{lcc}
\hline Region & Power grid & $\mathrm{RF}_{\mathrm{CO}_{2}}\left(\mathrm{t}-\mathrm{CO}_{2} / \mathrm{MWh}\right)$ \\
\hline Liaoning & Northeast & 0.9635 \\
Shanghai and Anhui & East & 0.7931 \\
Guangdong & Southern & 0.7906 \\
\hline
\end{tabular}

where $\mathrm{RF}_{\mathrm{CO}_{2}}\left(\mathrm{t}-\mathrm{CO}_{2} / \mathrm{MWh}\right)$ is the $\mathrm{CO}_{2}$ emission reduction factor. $\mathrm{EG}(\mathrm{MWh} / \mathrm{yr})$ is the electricity generated annually by the PV system. We used the baseline emission factor, EF, from the Clean Development Mechanism (CDM) for PV installation projects as the value for $\mathrm{RF}_{\mathrm{CO}_{2}}$. The values of $\mathrm{RF}_{\mathrm{CO}_{2}}$ differ depending on power grid and are listed in Table 1 . The $\mathrm{EF}$ for each region is obtained using the "Consolidate methodology for grid-connected electricity generation from renewable sources" [16] and using the following equation with values of operating margin $\mathrm{CO}_{2}$ emission factor, $\mathrm{EF}_{\mathrm{OM}}$, Build Margin $\mathrm{CO}_{2}$ emission factor, $\mathrm{EF}_{\mathrm{BM}}$, weighting of operating margin emission factor, $w_{\mathrm{OM}}=0.75$, weighting of build margin emission factor, $w_{\mathrm{BM}}=0.25[17,18]$ :

$$
\mathrm{EF}=\mathrm{EF}_{\mathrm{OM}} \times w_{\mathrm{OM}}+\mathrm{EF}_{\mathrm{BM}} \times w_{\mathrm{BM}} .
$$

\section{Results and Discussion}

In this chapter, detailed results for Liaoning are shown and discussed first. Next, results for Shanghai, Anhui, and Guangdong are shown and we finally discuss the regional differences by comparing each result.

\subsection{Results for Liaoning}

4.1.1. Available Area for Large-Scale PV Systems. Figure 4 shows the circular area situated at a distance and width of
$4 \mathrm{~km}$ from the outer limits of area with population densities greater than 5,000 people per $\mathrm{km}^{2}$ to the circumference of the circle in Liaoning. It is shown that the large number of circular area is located in the central district of Liaoning. Figures 5 and 6 show the distribution of slope angle and grassland, unused land in Liaoning, respectively. From Figure 5, it is found that most of central district of Liaoning has the land with slope angle less than 1\%. It is shown from Figure 6 that the large amount of area with grassland or unused land is located in the western districts of Liaoning.

Figure 7 shows the available area for large-scale PV systems in each district of Liaoning. Jinzhou has the largest available area, $36.6 \mathrm{~km}^{2}$, because it has a large amount of grassland or unused land with slopes less than $1 \%$. Shenyang, Huludao, and Chaoyang also have larger available area as compared to the other districts, because there are large areas of grassland and unused land. On the other hand, Benxi and Fushun have very little available area because of their small amount of the circular area with slope less than $1 \%$ and with grassland or unused land. Panjin has no available area despite all land in its circular area with slope less than $1 \%$. The total available area for installation is estimated to be $144.74 \mathrm{~km}^{2}$ in Liaoning.

4.1.2. Installation Capacity of a Large-Scale PV System. Figure 8 shows the installation capacity of a large-scale PV system at availability rate $100 \%$ in each district of Liaoning. The districts with the largest available area have the largest amount of installation capacity. Jinzhou is estimated to have the largest installation capacity of $749 \mathrm{MW}$ at availability rate $100 \%$. A PV system larger than $20 \mathrm{MW}$ cannot be installed in Benxi, Fushun, Tieling, Dandong, and Panjin.

Figure 9 shows the total installation capacity in Liaoning at availability rates from $50 \%$ to $100 \%$. Installation capacity has not been derived for availability rates from $10 \%$ to 


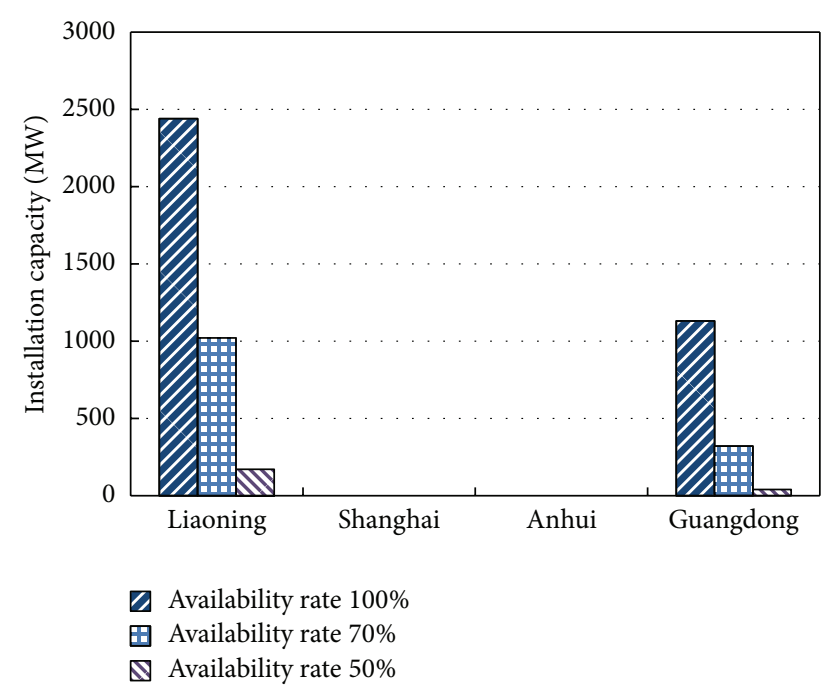

FIGURE 12: Installation capacity at each availability rate (50\%, 70\%, and $100 \%$ ) in each region.

$40 \%$, because a PV system larger than $20 \mathrm{MW}$ needs more than $0.46 \mathrm{~km}^{2}$ for installation. The total installation capacity in Liaoning is estimated to be $2,439.4 \mathrm{MW}$. This value is equivalent to $10.4 \%$ of the maximum power demand of $23,940 \mathrm{MW}$ [19]. At lower availability rates of $70 \%$ and $50 \%$, the installation capacity in Liaoning is estimated to be 1,021.0 MW, and 171.8 MW respectively. The installation capacity at lower rates is more likely installed, because the area margin is more sufficiently accounted for.

4.1.3. Electricity Generated and $\mathrm{CO}_{2}$ Emission Reduction. Figure 10 shows the total amounts of electricity generated and $\mathrm{CO}_{2}$ emission reduction by installation capacity at availability rate $100 \%$ in each district of Liaoning. Jinzhou has the largest amount of electricity generated, $913.5 \mathrm{GWh} / \mathrm{yr}$, and $\mathrm{CO}_{2}$ emission reduction, $880.2 \mathrm{kt}-\mathrm{CO}_{2} / \mathrm{yr}$.

Benxi, Fushun, Panjin, Dangdong, and Teiling are estimated to have no electricity generated and $\mathrm{CO}_{2}$ emission reduction. These values mainly depend on the difference in installation capacity because there is little difference in solar irradiation and ambient temperature between districts and also the reduction emission factor, $\mathrm{RF}_{\mathrm{CO}_{2}}$, is a constant value with regard to each district.

\subsection{Comparison of the Results Between Different Regions}

4.2.1. Comparison of the Available Area and Installation Capacity. Figure 11 shows the circular area situated at a distance and width of $4 \mathrm{~km}$ from the outer limits of area with population densities greater than 5,000 people per $\mathrm{km}^{2}$ to the circumference of the circle in each region. The total amount of circular area and the available area for large-scale PV systems in each region are shown in Table 2. Liaoning has the largest amount of the available area because it has a lot of the circular area that have a large amount of grasslands or unused lands with slopes less than $1 \%$. While Anhui and Guangdong have larger amount of the circular area than that of Liaoning, the

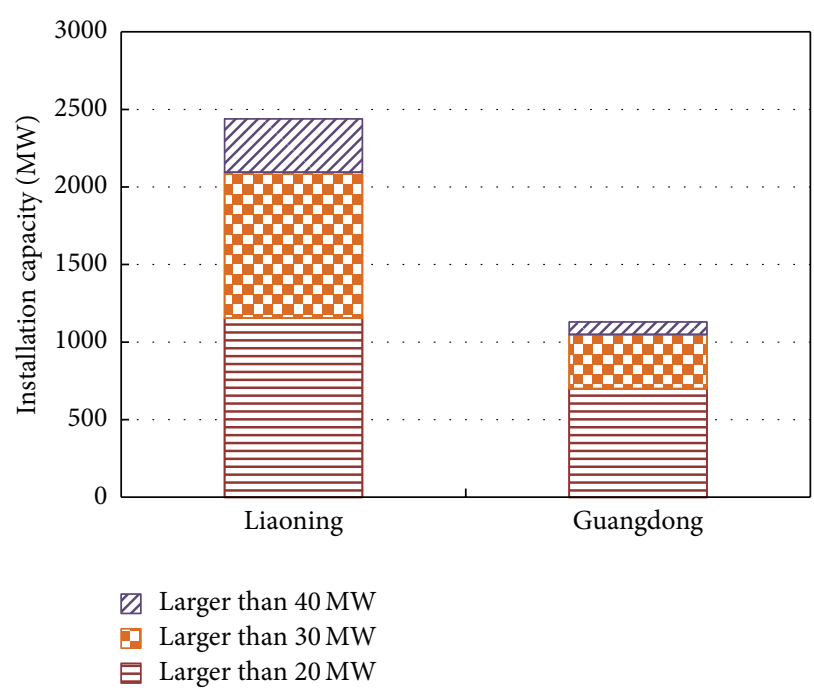

FIGURE 13: Scale of installation capacity at availability rate $100 \%$.

available area of Anhui and Guangdong is smaller than that of Liaoning. The reason is that Anhui and Guangdong has smaller grassland or unused land in a lot of circular area. Shanghai has no available area, since it has smaller amount of circular area and there are no grassland or unused land in its circular area.

Figure 12 shows the installation capacity of a large-scale PV system at availability rates $(50 \%, 70 \%$, and $100 \%)$ in each region. For each availability rate, a PV system lager than $20 \mathrm{MW}$ cannot be installed in Shanghai and Anhui. At availability rate of $100 \%$, Liaoning is estimated to have a capacity of 2,439.4 MW, which is the largest installation capacity. The installation capacity in Guangdong is estimated to be 1,131.2 MW. At lower availability rates $70 \%$ and $50 \%$, the installation capacity in Liaoning is estimated to be 1,021.0 MW and 171.82 MW, respectively. In Guangdong, the installation capacity is estimated to be $321.6 \mathrm{MW}$ and 40.7 MW, respectively.

Table 3 lists the ratio between installation capacity at availability rates of $100 \%$ and peak demand for electricity in each region. The installation capacity in Liaoning, $2,439.4 \mathrm{MW}$, is equivalent to $10.4 \%$ of the peak demand $23,470 \mathrm{MW}$ [19]. The installation capacity in Guangdong is equivalent to $1.5 \%$ of its peak demand $74,540 \mathrm{MW}$ [20]. The ratio between installation capacity and peak demand of Shanghai and Anhui is equivalent to $0 \%$ since each region has no installation capacity.

Figure 13 shows the amount of installation capacity for each scale (larger than $20 \mathrm{MW}$ or $30 \mathrm{MW}$ or $40 \mathrm{MW}$ ) at availability rate of $100 \%$ in Liaoning and Guangdong. In Liaoning, the installation capacity in case of larger than $30 \mathrm{MW}$ amounts to $52.6 \%$ of its total capacity, which is higher than Guangdong. Liaoning has much continuous available area. Thus, it is supposed that large scale PV system is able to be installed in Liaoning.

4.2.2. Comparison of the Electricity Generated and $\mathrm{CO}_{2}$ Emission Reduction. Table 4 lists annual electricity generated in 


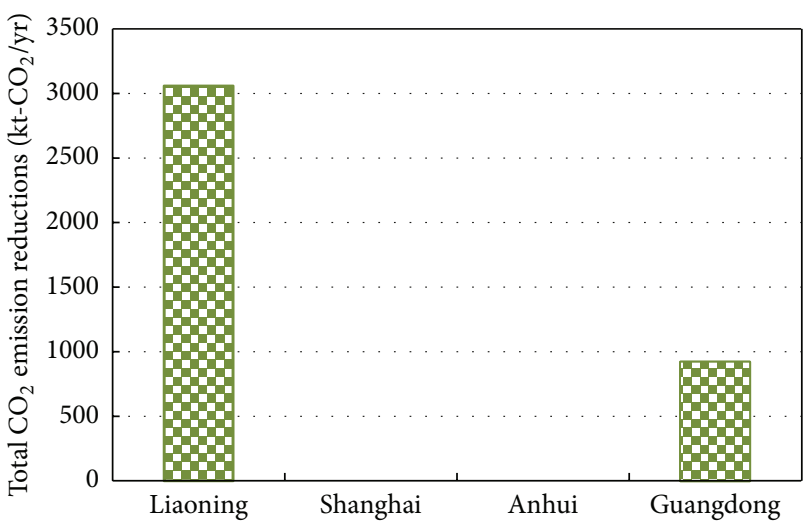

FIGURE 14: Total $\mathrm{CO}_{2}$ emission reduction in each region.

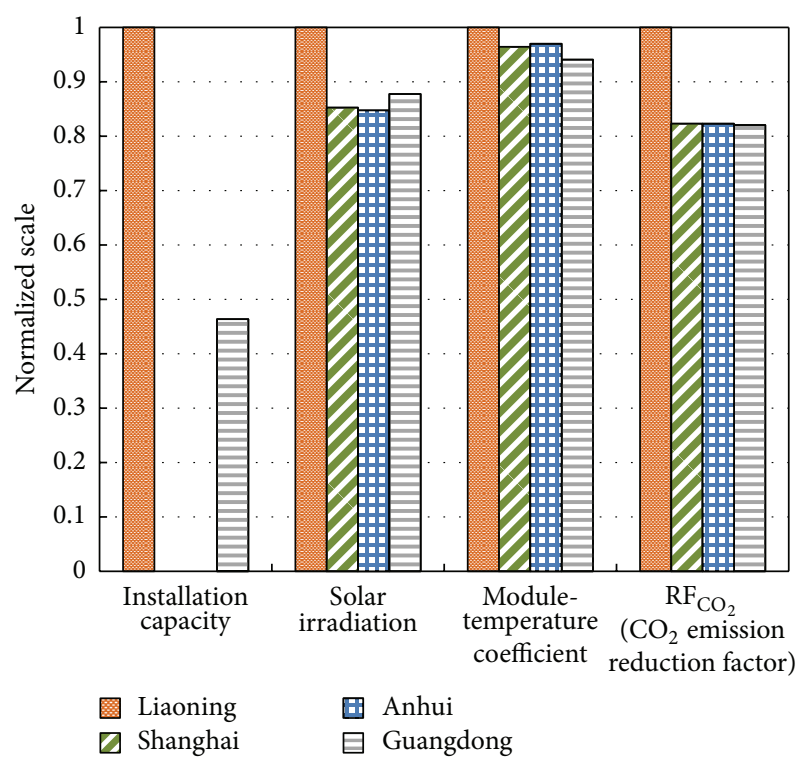

FIGURE 15: Overall comparisons on a normalized scale.

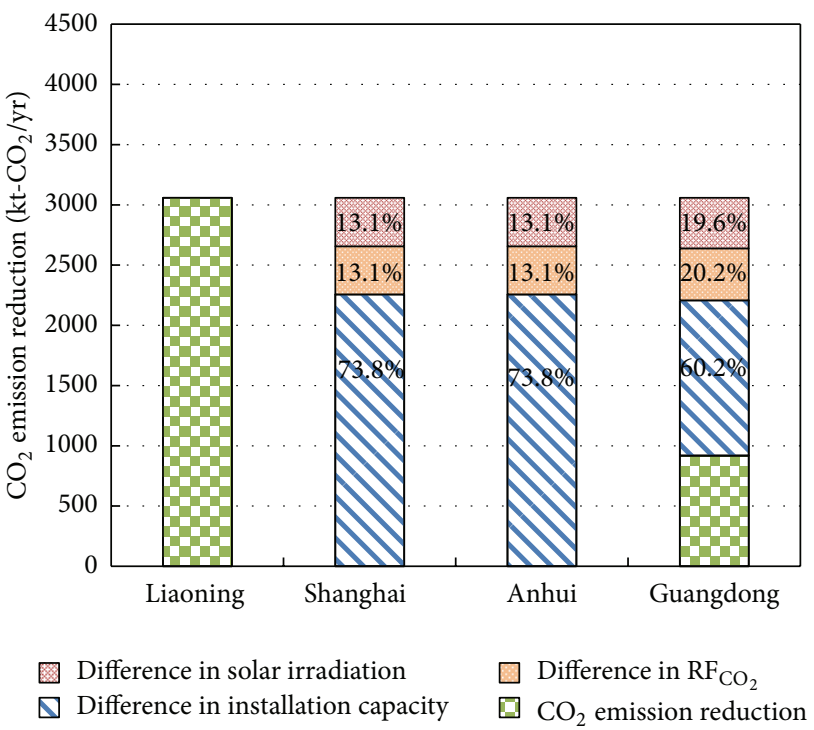

FIGURE 16: Details of the differences in the total amount of $\mathrm{CO}_{2}$ emission reduction in each region.
TABLE 2: Total circular area and available area.

\begin{tabular}{lcccc}
\hline Region & Liaoning & Shanghai & Anhui & Guangdong \\
\hline Circular area $\left(\mathrm{km}^{2}\right)$ & 16,452 & 1,653 & 22,441 & 19,333 \\
Available area $\left(\mathrm{km}^{2}\right)$ & 144.7 & 0 & 0.6 & 77.9 \\
\hline
\end{tabular}

TABLE 3: Ratio between installation capacity at availability rate $100 \%$ and peak demand in each region.

\begin{tabular}{lcccc}
\hline Region & Liaoning & Shanghai & Anhui & Guangdong \\
\hline $\begin{array}{l}\text { Installation capacity } \\
(\mathrm{MW}) \text { (Availability rate }\end{array}$ & $2,439.4$ & 0 & 0 & $1,131.2$ \\
$\begin{array}{l}\text { 100\%) } \\
\begin{array}{l}\text { Ratio between } \\
\text { installation capacity and } \\
\text { peak demand (\%) }\end{array}\end{array}$ & 10.4 & 0 & 0 & 1.5 \\
\hline
\end{tabular}

TABLE 4: Comparison of electricity generated in each region (GWh/ yr).

\begin{tabular}{lcccc}
\hline Region & Liaoning & Shanghai & Anhui & Guangdong \\
\hline $\begin{array}{l}\text { Total electricity } \\
\text { generated (2010) [15] }\end{array}$ & 134,000 & 94,400 & 146,300 & 314,600 \\
$\begin{array}{l}\text { Total electricity } \\
\text { generated by installation } \\
\text { capacity of PV systems }\end{array}$ & 3,174 & 0 & 0 & 1,162 \\
\hline
\end{tabular}

2010 and by installation capacity of large-scale PV system in each region. In Liaoning, the total electricity generated by the installation capacity of large-scale PV system at availability rate $100 \%$ is estimated to be $3,174 \mathrm{GWh} / \mathrm{yr}$ which is equivalent to $2.4 \%$ of its total electricity generated in 2010 [15]. In Guangdong, the total electricity generated by installation capacity of large-scale PV system at availability rate $100 \%$ is estimated to be $1,162 \mathrm{GWh} / \mathrm{yr}$ which is equivalent to $0.4 \%$ of its total electricity generated in Guangdong in 2010 [15].

Figure 14 shows the total $\mathrm{CO}_{2}$ emission reductions by the total electricity generated by installation capacity of largescale PV system at availability rate $100 \%$. The amount of total $\mathrm{CO}_{2}$ emission reduction is estimated to be $3,058 \mathrm{kt}-\mathrm{CO}_{2} / \mathrm{yr}$ in Liaoning and $919 \mathrm{kt}-\mathrm{CO}_{2} / \mathrm{yr}$ in Guangdong.

4.2.3. Key-Factor Analysis. Figure 15 shows a comparison of the $\mathrm{CO}_{2}$ emission reduction in each region on a common normalized scale ranging from 0 to 1 on the basis of the following factors, namely, the installation capacity at availability rate of $100 \%$, the solar irradiation, the module-temperature coefficient, and the $\mathrm{RF}_{\mathrm{CO}_{2}}$. This method makes it simpler to compare the results of this study, since 1 represents the best and 0 represents the worst for each factor. From the figure, the difference in the total $\mathrm{CO}_{2}$ emission reduction is affected significantly by the difference in the installation capacity. The difference in the module-temperature coefficient has little effect on the differences in $\mathrm{CO}_{2}$ emission reduction.

Differences in $\mathrm{RF}_{\mathrm{CO}_{2}}$ mainly affect the $\mathrm{CO}_{2}$ emission reduction from a $20 \mathrm{MW}$ PV system, since differences in the total installation capacity are unrelated. In this case, $\mathrm{RF}_{\mathrm{CO}_{2}}$ 
has more influence on $\mathrm{CO}_{2}$ emission reduction than solar irradiation between Liaoning and the other regions.

Figure 16 shows the key-factor analysis with normalization and the following are the details of the differences in the total amount of $\mathrm{CO}_{2}$ emission reduction between Liaoning and the other regions. Between Liaoning and Shanghai or Anhui, the installation capacity occupies $73.8 \%$, and the difference in the solar irradiation including the moduletemperature coefficient and the $\mathrm{RF}_{\mathrm{CO}_{2}}$ is $13.1 \%$. Between Liaoning and Guangdong, the installation capacity occupies $60.2 \%$, and the difference in the solar irradiation including the module-temperature coefficient and the $\mathrm{RF}_{\mathrm{CO}_{2}}$ is $19.6 \%$ and $20.2 \%$, respectively.

\section{Conclusions}

The present study shows the installation capacity of largescale PV systems, electricity generated, and $\mathrm{CO}_{2}$ emission reduction by the installation capacity of PV system in Liaoning, Shanghai, Anhui, and Guangdong considering regional differences.

The installation capacity of large-scale PV systems in Liaoning is estimated to be largest because its available area, namely, the grassland and unused land, for large-scale PV systems is larger than the other regions. The amount of total electricity generated and $\mathrm{CO}_{2}$ emission reduction by the installation capacity in Liaoning is more 2.7 times larger than the other regions.

From the results obtained by key-factor analysis, the total $\mathrm{CO}_{2}$ emission reduction is affected by three factors, significantly by the difference in the installation capacity. The difference in the installation capacity is more than 3 times larger than that in solar irradiation and $\mathrm{RF}_{\mathrm{CO}_{2}}$. The difference in the $\mathrm{CO}_{2}$ emission reduction factor is not negligible between Liaoning and Guangdong because it is $20.2 \%$. Based on the results of the evaluations performed in this study, it is expected that $\mathrm{CO}_{2}$ emission reduction by installing large-scale PV system will be larger in the region that has larger installation capacity.

\section{Acknowledgment}

This research was supported by the Environment Research and Technology Development Fund (E-1001) of the Ministry of the Environment, Japan.

\section{References}

[1] IEA, World Energy Outlook 2010, The International Energy Agency, 2010.

[2] IEA, $\mathrm{CO}_{2}$ Emissions from Fuel Combustion Highlights, The International Energy Agency, 2011.

[3] M. Hart, China Goes Solar as America Stumbles New Five-Year Plan Boasts Big Ambitions, Center for American Progress, 2011.

[4] D. Zhang, Q. Chai, X. Zhang et al., "Economical assessment of large-scale photovoltaic power development in China," Energy, vol. 40, no. 1, pp. 370-375, 2012.
[5] M. Ito, K. Kato, H. Sugihara, T. Kichimi, J. Song, and K. Kurokawa, "A preliminary study on potential for very largescale photovoltaic power generation (VLS-PV) system in the Gobi desert from economic and environmental viewpoints," Solar Energy Materials and Solar Cells, vol. 75, no. 3-4, pp. 507$517,2003$.

[6] J. Byrne, A. Zhou, B. Shen, and K. Hughes, "Evaluating the potential of small-scale renewable energy options to meet rural livelihoods needs: a GIS- and lifecycle cost-based assessment of Western China's options," Energy Policy, vol. 35, no. 8, pp. 43914401, 2007.

[7] SWERA, "Solar: monthly and annual average latitude tilt GIS data at $40 \mathrm{~km}$ resolution for China from NREL," 2005, http:// en.openei.org/apps/SWERA.

[8] J. A. Carrión, A. E. Estrella, F. A. Dols, and A. R. Ridao, "The electricity production capacity of photovoltaic power plants and the selection of solar energy sites in Andalusia (Spain)," Renewable Energy, vol. 33, no. 4, pp. 545-552, 2008.

[9] Beijing GeoTechway, "China resources and environment $1 \mathrm{~km}$ resolution grid data sets," 2003.

[10] China Historical GIS, "DEM raster dataset," 2013, http://www .fas.harvard.edu/ chgis/.

[11] NREL, Potential for Development of Solar and Wind Resource in Bhutan, National Renewable Energy Laboratory, 2009.

[12] K. Kawajiri, T. Oozeki, and Y. Genchi, "Effect of temperature on PV potential in the world," Environmental Science and Technology, vol. 45, no. 20, pp. 9030-9035, 2011.

[13] NEDO, For Effective Performance of Photovoltaic System, New Energy and Industrial Technology Development Organization, 2010.

[14] Japan Meteorological Agency, The World Surface Data, Japan Metrological Business Support Center, 2009.

[15] Editorial committee of China Electric Power Yearbook, China Electric Power Yearbook 2011, China Electric Power Press, 2011.

[16] United Nations Framework Convention on Climate ChangeExecutive Board, "ACM0002: consolidated baseline methodology for grid connected electricity generation from renewable sources-version 12.2.0," 2011.

[17] United Nations Framework Convention on Climate ChangeExecutive Board, "Methodological tool "Tool to calculate the emission factor for an electricity system" (version 02.2.1)," 2012, http://cdm.unfccc.int/methodologies/PAmethodologies/tools/ am-tool-07-v2.2.1.pdf.

[18] National Development and Reform Commission, "2011 baseline emission factors for regional power grids in China," 2011, http:// cdm.ccchina.gov.cn/WebSite/CDM/UpFile/File2720.pdf.

[19] State Grid Corporation of China, "The new record of the peak power demand in Liaoning," 2010, http://www.indaa.com.cn/ zt/hlgc/dbdw/201011/t20101117_450261.html.

[20] Guangdong Grid Corporation of China, "The power demand in Guangdong exceeded ten billion," 2011, http://news.sohu.com/ 20111221/n329794116.shtml. 


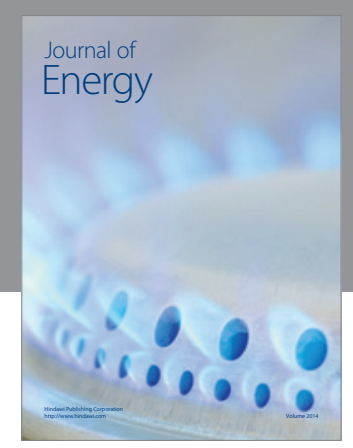

Journal of

Industrial Engineering
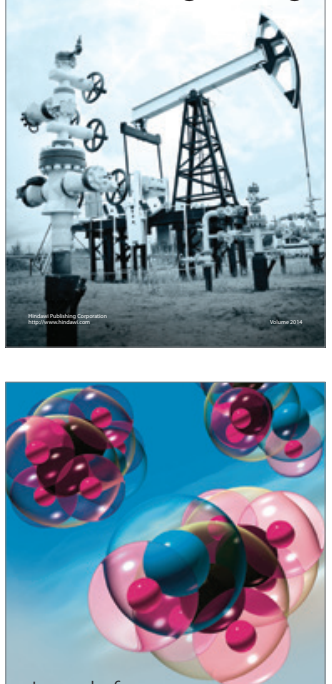

Fuels
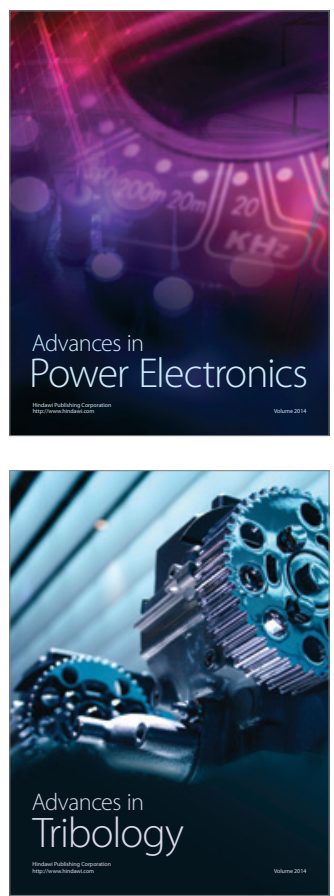

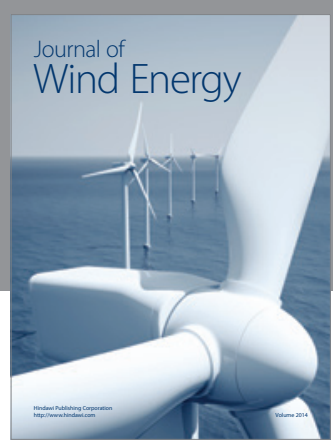

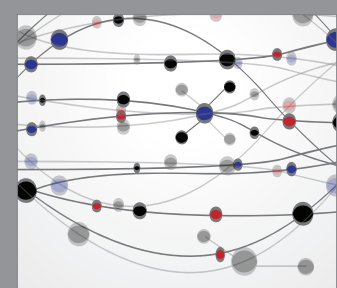

The Scientific World Journal

Submit your manuscripts at http://www.hindawi.com

Journal of

Structures
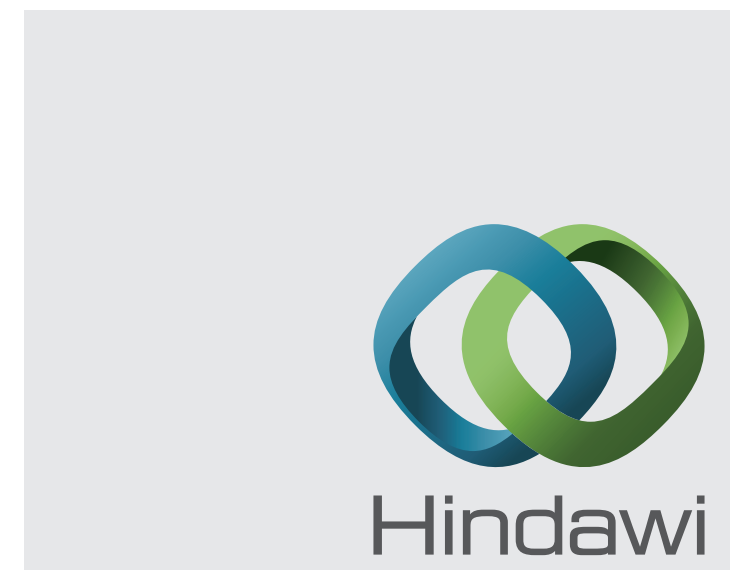

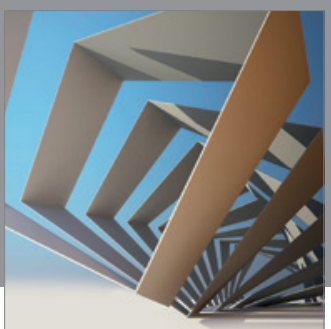

Rotating

Machinery
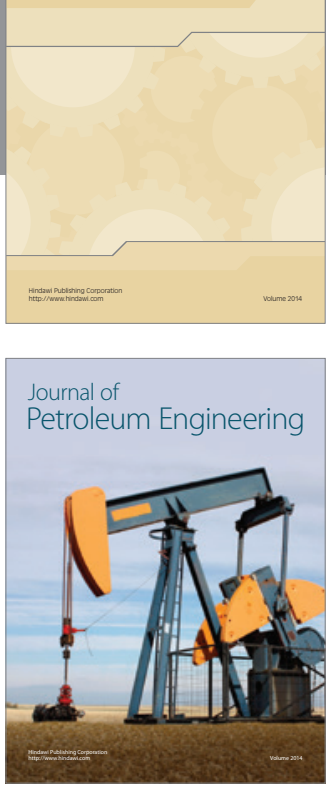

Journal of

Solar Energy
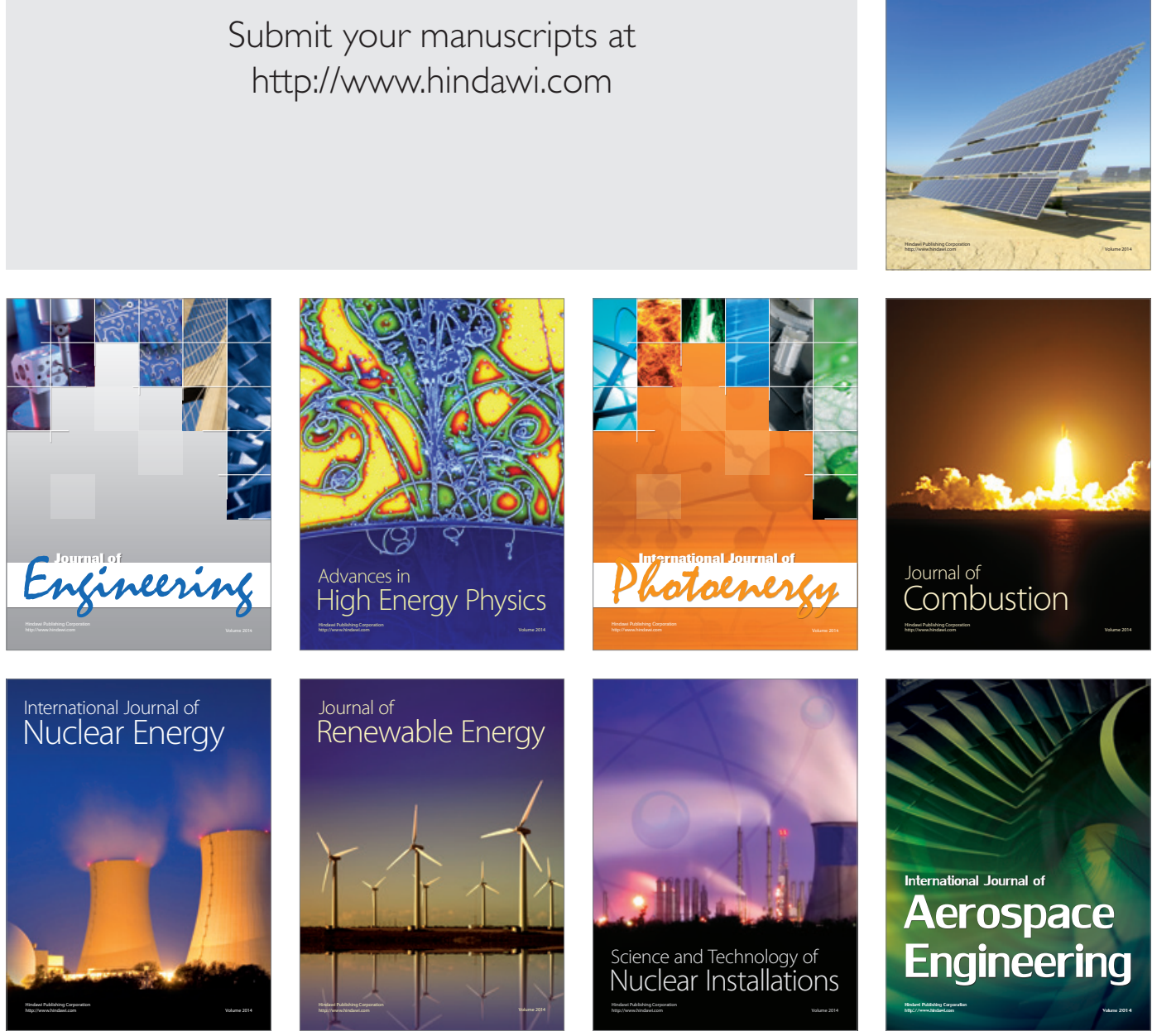